\title{
Scaffolding as effective method for mathematical learning
}

\author{
Parvaneh Amiripour ${ }^{1}$, Somayeh Amir-Mofidi ${ }^{2 *}$ and Ahmad Shahvarani ${ }^{3}$ \\ ${ }^{1}$ Department of Mathematics, Shahr-e Rey Branch, Islamic Azad University, Tehran, Iran \\ ${ }^{2,3}$ Department of Mathematics, Science and Research Branch, Islamic Azad University, Tehran, Iran \\ *Somayeh.Amirmofidi@mailfa.org
}

\begin{abstract}
Scaffolding is a mechanism for observing the process by which a learner is helped to achieve his or her potential learning. Regard to nature of scaffolding, it seems that scaffolding process can have an effect on learning and teaching procedure. In the present study, researchers have studied primary nature of scaffolding method in mathematical learning, then introduced mathematical samples through scaffolding method. Finally researchers have provided many strategies for better implementation of scaffolding method on mathematical learning and teaching.
\end{abstract}

Keywords: Mathematics, Scaffolding, Education, Zone of proximal development (ZPD), Learning

Introduction

One of the main concepts of Vygotsky' theory is the zone of proximal development (ZPD) and its perception is important for cognitive development theory. This theory shows the important social communication in learning and growth. Piaget (1973) believed that development is preferable on learning. But Vygotsky (1981) stated that learning occurred before development. Piaget indicated that phase of cognitive development that child stands in it is a determinant of her/his learning nature and then we cannot teach beyond cognitive development of child. Inverse Vygotsky (1978) believed that development process follows the learning process. Vygotsky (1978) has indicated that child, who cannot do self-tasks, can do self-tasks via help of more conscious parents or teachers. That is when the child believes only until he/she is able to solve problems independently then he/she shows one of the kinds of self-capacities and when he/she solves the problems via conscious people then he/she shows more capacities. The capacity of a child in solving the problem independently, is an indicator of the current level of her/his development. Her/his-capacities in problem solving via help of conscious people is an indicator of potential level of her/his development. The mean of Vygotsky of ZPD term is the difference between two cited levels. Based on this definition, ZPD is tasks that child cannot do only but he/she can do it via help of conscious people (Berk, 2000). Low level of ZPD is the capacity of problem solving that child can get to it only and its high level is indicator of extra responsibility level that child can get to it via help of teacher or instructor (Santrock, 2004). Therefore when cognitive development is extreme social communication occurs in ZPD. The zone of proximal development (ZPD) includes of tasks that child has learned yet but he/she has ready for its learning (Slavin, 2006). As it is cited, tasks which stand in ZPD, it is not learning via child yet. If teachers or parents helped the child then child will learn the tasks. These guidance and assistance of parents and teachers is called as scaffolding (Woolfolk, 2004). Scaffolding is the direction

Sci.Technol.Edu.

(C)Indian Society for Education and Environment (iSee) process of learner for passing whatever knew to whatever will learn. In scaffolding, teacher or every person has responsibility in learning process firstly and when learning occurs gently, then learner will has the responsibility in learning process. The notion of "scaffolding" was developed in the context of dyadic interaction between a parent and their very young child or between an adult and a very young child (Bruneret al., 1983)-a context that quite differs from the school context in the way that "discourse between a teacher and an individual pupil is usually contextualized by other discourse, whereby the pupil relates to the teacher as part of a group or whole class" (Maybin et al., 1992). Mathematics teachers have the responsibility to direct and shape the learning opportunities of their students. Evidence is now emerging that curricula and teaching practices consistent with some recent efforts toward educational reform show promise for improving students' learning of mathematical skills with deeper conceptual understanding (Briars et al., 2000). One of the challenges in mathematics education is the weak relation between teacher and their students for mathematical learning. In this research, researchers have tried that explained these challenges and introduced the efficiency strategies for better learning and teaching process.

\section{Learning and teaching through scaffolding method}

Instructional scaffolding is a mechanism for observing the process by which the learner is helped to affect his or her potential learning (Stone, 1993). Practically speaking, it refers to the "provision of guidance and support which is increased or withdrawn in response to the developing competence of the learner" (Mercer, 1995), and it is based on the appropriation, not simple transfer, of ideas between teacher and student. However, understanding the subtle ties by which this occurs is a complex process that requires sensitivity to the learner's goals as these goals emerge in the course of activity (Wells, 1999). Thus, within the classroom, scaffolding presupposes that the teacher is continuously attending to students' thinking in order to access their individual (and communal) ZPD. 
Vygotsky (1978) took the Piagetian idea of the child as an active learner further, putting emphasis on the role of social interaction in learning and development. Vygotsky (1978) viewed children and adults as both being active agents in the process of child's development. In this case, the quality of interaction between the children and the adult which are dialogical in nature and based in the respect of children's interests and needs, become essential (Bodrova \& Leong 1996). The metaphor of scaffolding, however, doesn't capture the two-way relationship between the teacher and a student, but rather implies a one-sided view of this relationship where a teacher provides a support for the learner. The quality of teacher intervention in education has been largely associated with scaffolding. The metaphor remains increasingly popular among in-service and pre-service teachers and early childhood educators. Indeed, the metaphor of scaffolding based in socio-cultural theories and widely accepted by educators, can be an effective tool in meeting needs of learners in various scopes such as mathematical learning. Eggen and Kauchak (2001) have introduced samples of scaffolding that teacher have effective communication to her/his student. In Table 1, it is shown these samples.

Table 1. Samples of educational scaffolding

\begin{tabular}{|l|l|}
\hline \multicolumn{1}{|c|}{$\begin{array}{c}\text { Educational } \\
\text { scaffolding }\end{array}$} & \multicolumn{1}{c|}{ Example } \\
\hline Pattering & $\begin{array}{l}\text { Teacher draws figure for students } \\
\text { then he/she asks them that must draw } \\
\text { respected figure independently. }\end{array}$ \\
\hline Aloud thinking & $\begin{array}{l}\text { Physics teacher when solves a } \\
\text { physics problem, states her/his } \\
\text { thinking. }\end{array}$ \\
\hline $\begin{array}{l}\text { Using educational } \\
\text { materials }\end{array}$ & $\begin{array}{l}\text { Coach shuts basketball net until child } \\
\text { practices to drop of ball then coach } \\
\text { uplifts the net. }\end{array}$ \\
\hline $\begin{array}{l}\text { Using guidance } \\
\text { and gesture }\end{array}$ & $\begin{array}{l}\text { Instructor of kindergarten tells to child } \\
\text { that rabbit rolls on the hole then } \\
\text { jumps to it! Instructor learned to } \\
\text { tighten the laces. }\end{array}$ \\
\hline
\end{tabular}

In this section, researchers have studied the mathematical learning and teaching process via scaffolding (effective interaction between teacher and students). Two following samples indicate the scaffolding process:

Sample1. A student cannot do "division operation" correctly. Teacher teaches to this student via effective interaction or scaffolding.

Firstly teacher writes $44: 6$ on blackboard for this student. Then teacher asks student that;

Teacher: which number can we multiply in 6 that its solution nears to 44 ?

Student: 6

Teacher. he writes 6 on blackboard then he asks student what is $6 \times 6$ ?

Student: 36
Teacher: he deletes 6 and writes 36. Then he asks that can you select other number that its solution is more near to 44 ?

Student: 8

Teacher: what is $6 \times 8$ ?

Student: 48

Teacher: 48 is very large. Can you find other number?

Student: $6 \times 7=42$. Then 42 is more near to 44 .

In the sample 1, we observed that effective interaction between teacher and student is made to encourage the mathematical learning process for this student. Effective scaffolding occurred when teacher asks students that find suitable number until get to 44 . Here student is noticed that he/she must find a number that nears to 44. His/her misconception or mistake is removed.

Sample 2. Many students have not learn the solving linear equation systems. Teacher tries that teaches via efficiency scaffolding.

Teacher: he writes one example of sample linear equation system; $\left\{\begin{array}{l}x+y=1 \\ x-y=2\end{array}\right.$ then he asks that students must find the values of $x, y$.

Students: we do not know how we began.

Teacher: It is better that you must find the y value firstly. Students: Why?!!

Teacher: In my opinion, $y$ in $x+y=1$ with $y$ in $x-y=2$ is symmetry. If we add both equations then $y$ values will remove then $x$ values will remain.

Students: Then we must find the symmetry values then we calculated remained values!! It is interesting!!

Teacher: try it.

(Students added two equations and remove the $y$ values of two equations).

Students: That's right, $\left\{\begin{array}{l}x+y=1 \\ x-y=2 \\ 2 x=3\end{array}-\right.$, then $x=\frac{3}{2}$. Okay,

now how do we find $y$ value?

Teacher: Please replace the $x$ value in first equation or second equation.

Students: It's interesting, we try it. (They have tried and get to $y$ value). We tried and replaced $x$ value in second equation then we observed that same value is gotten!!

Teacher: What are you noticed of this matter?

Students: In solving these equations, we fellow symmetry values or we can do one operation that one of the values became symmetry at least.

As shown in above sample, teacher began one constructive strategy through scaffolding, then students are noticed where their mistakes occurred before. As it is observed, in middle phase of these interactions, teacher leaves their students only until their effort. Sometimes students find and solve respected problem only that is determined that educational scaffolding is effective but sometimes students cannot solve problem correctly and
Sci.Technol.Edu.

CIndian Society for Education and Environment (iSee)
"Mathematical learning"

http://www.indjst.org
P.Amiripour et al. Indian J.Sci.Technol. 
teacher helps to them. When scaffolding was effective then teacher do not enter to the interaction.

Suggestions for using scaffolding method

In this section, we introduce suggestions for using scaffolding method in mathematics classes. These suggestions can promote the mathematical learning and motivation in classes.

\section{Use of pattering}

Teachers or instructors should use of patterning. While teaching a mathematical problem, first one need not denote expressly but make to prevail creative potential and encourage solving the problem. These interactions between teacher and self-students can be of effective scaffolding.

\section{Use of feedbacks}

When you have designed the problem and have began the scaffolding then you should use the feedback. If you did not use feedback then students will not notice whether their suggestions was effective on problem solving. If students introduced the corrective solution then you indicate positive feedback and if it was not this form then you should use negative feedback carefully. Of course positive feedbacks will be more effective.

\section{Organize students' responses}

When you started the scaffolding, you must be noticed that students' responses do not stray because it makes that students confused in scaffolding phases and they will not comprehend ultimately. Then try to organize and predict their responses until you have effective scaffolding phases.

\section{Use of instrumental instructors}

In scaffolding method, teachers or instructors began this process often and students will learn through the process. But we can use other instruments as teachers or instructors! For example, in present decade we use of computers, software or electronic instruments. Mathematical software can be applied in mathematical class. In these classes, scaffolding process will be different. Human communication will become one party. Many students cannot communicate to their teachers but they can better communicate to electronic instruments such as software. Notice that all students are not same and we must not neglect them. Of course teachers must supervise their learning process after using these electronic instruments whether these students have learned.

\section{Use of student as instructor}

When learning occurs in scaffolding process, students who learnt can teach others. Instructor or teacher can make lerned students to teach other students. This process motivates students to learn further. When student teaches his/her own classmates, self-mistakes are corrected easily.

\section{Remove misconceptions}

Scaffolding method can denote kinds of misconceptions in problem solving process. Maybe scaffolding is only method that determines the misconceptions that occur via students. Scaffolding as effective method which can remove misconceptions. Teacher or instructor must notice and provide direct scaffolding procedure precisely. When student indicates self-misconception/s then teacher or instructor must teach and remove misconception then he/she can continue.

\section{Use of real problems}

In scaffolding procedure, teacher or instructor can apply real problems. When student interferes in real problems then student can relate to self-life. Citing real problems as an example can lead to meaningful learning because student can aloud think about respected mathematical problem in scaffolding process then relates to self-mind and self-around until be able response to problem. In this moment, meaningful learning will occur and student can motivate to problem solving and it's interesting that student will not has fear of difficult problem and can solve via teacher or instructor.

\section{Conclusion and discussion}

This study provides an opportunity for introducing mathematical learning and teaching via scaffolding method. Scaffolding is defined as the teaching-andlearning process, wherein the adult sets mental scaffolds through talk, offering a vicarious form of consciousness in order for the child to be able to move into his/her Zone of Proximal Development (ZPD) and advance from the dependent competence to the independent competence. This process continues with the adult gradually withdrawing the mental "scaffolds" as the child presents an increasing independent competence and finishes when the child is capable to do on their own what, up to that point, was possible only with the help of the adult.

The results of prior studies have indicated that students' capacity to engage in types of discussions is a habit of mind that can be scaffold through the teacher's trans-active prompts and facilitative utterances. In fact students can promote social communication and ultimately they can learn mathematics contexts correctly. There are reasons of scaffolding's successful process;1) this process can motivate to problem solving procedure for student, 2) scaffolding method will promote current level of student's capacities and social relations, 3) scaffolding process will increase self-confidence of student in difficult mathematical problem solving, and 4) this educational method can show the mistakes and misconceptions of students in solving procedure. Suggestions for future research includes; 1) study the scaffolding method in mathematical class statistically, 2) provide and distribute questionnaire for teachers and students for studying their opinions, 3) study this process in math exam.

Limitations of this research; 1) this research is limited to mathematics and be of descriptive research method. References

1. Berk LE (2000) Child development. Boston: Allyn \& Bacon.
Sci.Technol.Edu.

CIndian Society for Education and Environment (iSee)
"Mathematical learning" http://www.indjst.org
P.Amiripour et al. Indian J.Sci.Technol. 
2. Bodrova $E$ and Leong D (1996) The Vygotski an approach to early childhood. Columbus, Ohio:Merrill, Imprint of Prentice Hall.

3. Briars DJ and Resnick LB (2000) Standards, assessments-and what else? The essential elements of standards-based school improvement (CSE Technical Report 528). Retrieved September 28, 2008, from ttp://www.cse.ucla.edu/products/ Reports/TECH528.pdf

4. Bruner JS (1983) Child's talk: Learning to use language. Oxford: Oxford Univ. Press.

5. Eggen $P$ and Kauchak $D(2001)$ Educational psychology: Windows on classroom $\left(5^{\text {th }}\right.$ ed.).Upper saddle river, $\mathrm{NJ}$ : Merrill, Practice-Hall.

6. Maybin J, Mercer N andStierer B (1992) Scaffolding in the classroom. In K. Norman (Ed.), Thinking voices: The work of the National oracy project. London:Hodder and Stoughton.

7. Mercer N (1995) The guided construction of knowledge. Clevedon, UK Multilingual Matters.

8. Piaget J (1973) The child's conception of the world. London: Routlege.

9. Santrock JW (2004) Educational psychology $\left(2^{\text {nd }} \&\right.$ $3^{\text {rd }}$ ed.). NY.McGraw-Hill.

10. Slavin RE (2006) Educational psychology: Theory and practice $\left(8^{\text {th }}\right.$ ed.). NY. Pearson.

11. Vygotsky LS (1978) Mind in society: the development of higher mental process. Cambridge, MA. Harward Univ. Press.

12. Stone CA (1993) What is missing in the metaphor of scaffolding? In E. Forman, N. Minick, \& C.A.

13. Stone (1993), Contexts for learning: Sociocultural dynamics in children's learning. Oxford: OxfordUniv. Press.

14. Vygotsky LS (1981)The genesis of higher mental functions. In J.V. Wretsch (Ed.). The concept of activity in social psychology. Arnonk, NY.Sharpe.

15. Woolfolk AE (2004) Educational psychology $\left(10^{\text {th }}\right.$ ed.). Boston: Pearson.

16. Wells G (1999) Dialogic inquiry: Toward a sociocultural practice and theory of education.Cambridge.Cambridge Univ. Press. 